\title{
Population Database
}

National Cancer Institute

\section{Source}

National Cancer Institute. Population Database. NCI Thesaurus. Code C16126.

Example: SEER and other cancer registries 